\title{
The Benefit of L-Threonine Supplementation on Growth Performance, Carcass Characteristics, Intestinal Morphology and Litter Quality of Broilers.
}

\section{-Author(s)}

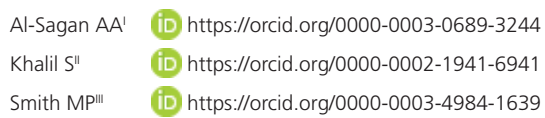

General Directorate of Research Grant, King Abdulaziz City for Science \& Technology, P.O. Box 6086, Riyadh 11442, Saudi Arabia.

Evonik Limited Egypt. City Stars, Nasr City, Egypt.

III Evonik Degussa GmbH. Hanau-Wolfgang, Germany.

\section{Mail Address}

Corresponding author e-mail address Ahmed A. Al-Sagan

King Abdulaziz City for Science and Technology, P.O. Box 6086, Riyadh 11442

Saudi Arabia.

Email: abdeen@kacst.edu.sa

\section{ABSTRACT}

This study was carried out to investigate the effect of dietary L-Threonine supplementation on broiler performance, carcass characteristics, duodenal histo-morphology and litter analysis. It was hypothesised that the overall broiler performance would be improved in threonine adequate diets with reduced environmental impact when using L-threonine supplementation. A total of 144-sexed Ross 308 broiler chicks were randomly allocated into 3 dietary treatments. Each treatment was replicated 6 times with 8 birds per replicate $(4$ male and 4 female). Treatment group 1 served as threonine deficient group, fed with a diet with all limiting amino acids met except threonine as no synthetic form was supplied. Treatment group 2 served as threonine adequate high crude protein, where L-Threonine adequacy was achieved with higher level of crude protein. Treatment group 3 served as L-Threonine adequate but achieved it through L-Threonine supplementation. Treatment effects on growth performance, carcass characteristics, intestinal morphology and litter quality were determined. Results compared to group 1 showed that group 3 at the end of the experimental period (28 days) had improved final body weight $P<0.05$, live and carcass weights $P<0.01$, dressing yields $P<0.05$, relative wing weights $P<0.01$ and relative heart weights $P<0.05$. However, group 2 showed numeric improvement in all aforementioned parameters but not enough to show significance. Litter moisture and nitrogen content was affected by dietary L-Threonine fortification $P<0.05$. The lowest moisture and nitrogen content were noticed in group 3. Meanwhile, group 2 showed the highest nitrogen and group 1 showed the highest moisture content among all groups. Intestinal villi length and villus: crypt ratio was affected by dietary treatments $P<0.001$ and $P<$ 0.05 respectively. Group 3 showed the highest villus length and villus: crypt ratio followed by group 2 and group 1. In conclusion correcting L-Threonine deficient diet by adding L-Threonine significantly improved live weight gain and carcass characteristics, while numerically improved feed conversion ratio and breast weight. Correcting the deficit by supplying crude protein had no significant effect. Additionally, dietary L-Threonine supplementation reduced environmental burden by reducing both litter nitrogen and moisture content.

\section{INTRODUCTION}

Threonine (Thr) is typically the third limited amino acid in broiler diets (Everett et al. 2010). An adequate digestible Thr level is needed to support optimum growth (Al-Hayani 2017), immune response (Ruth \& Field 2013) and gastrointestinal mucin production (Kidd and Tillman 2016). Experimental analysis indicates that the most important amino acids in the models of feed conversion ratio (FCR) and body weight gain were lysine and Thr, respectively (Mehri et al. 2012). A 
large portion of dietary Thr is used for the synthesis of intestinal mucosal proteins, such as mucin. Mucin is a glycoprotein and consists of peptides that are rich in Thr that was estimated to be close to a third of the proteins utilized in mucin (Corzo et al. 2007). Marginal dietary deficiencies of digestive Thr can result in economic losses due to increased FCR and reduced breast meat yields (Khan et al. 2008). Meeting the optimum dietary Thr levels with L-Thr supplementation allows poultry nutritionists to reduce dietary crude protein $(C P)$ level while improving nitrogen retention and reducing water loss to the environment (Zaghari et al. 2011). The decrease in nitrogen excretion could contribute towards alleviating current environmental concerns regarding acid rains and ground water pollution with excess nitrogen (Aletor et al. 2000).

In this context, the goal of the current study was to determine the impact of L-Thr supplementation on broiler performance, carcasscharacteristics, duodenal histo-morphology and litter analysis.

\section{MATERIAL AND METHODS}

\section{Experimental birds and diets}

One hundred forty-four (144) Ross 308 broilers were allocated randomly to 3 experimental treatments. Each treatment was replicated 6 times with 8 birds per replicate (4 males and 4 females). Stocking density was calculated in accordance to the targeted final live body weight $(1.54 \mathrm{~kg})$ to be $30.8 \mathrm{~kg} / \mathrm{m}^{2}\left(0.05 \mathrm{~m}^{2} /\right.$ Bird $)$. All treatments diets were corn-soya based, formulated to meet amino acid ratios according to AMINOChick ${ }^{\circledR} 2.0$ after specifying the target metabolisable energy and phase length. Birds of (G1) served as Thr-deficient group, while birds of $(\mathrm{G} 2)$ served as Thr-adequate high crude protein and the birds of (G3) served as Thr-adequate L-Thr group. Birds were fed in 2 phases; starter phase (3-14 days) and finisher phase (15-28 days). Feed samples from each phase (200 grams/group) were collected and sent to Evonik Lab where they were analyzed for chemical composition using AMINOLab ${ }^{\circledR}$. During the first two days, chicks were provided with a commercial diet to exclude any unspecific mortalities and variation in weights. Throughout the experiment, birds were fed mash feed and had free access to water; light and temperature were managed according to breed's recommendation.

\section{Sampling and measurements}

Sampled chicks and the remaining feed were weighed at the end of each phase to allow the calculations of body weight gain, feed intake, and FCR. Ten chicks from each group were randomly chosen for carcass characteristics analysis. Three autopsy samples were randomly taken from the duodenum in different groups, then they were fixed as recommended in $10 \%$ formal saline for 24 hours and they were then taken to the laboratory for histopathological examination (Caruso et al. 2012). The villus length was determined from the top of the crypts. The crypt depth was determined from its base to the crypt-villus transition using ImageJ program (Natl. Inst. of Health, USA). At day 28, litter samples were collected randomly from 3 pens from each group, weighed and then heated in a hot air oven at $105^{\circ} \mathrm{C}$ till constant weight and then the moisture content (\%) was determined. Of the litter samples, 100 grams were analysed for nitrogen content (\%) using Kjeldahl (at National Centre for Agricultural Technology, KACST).

\section{Statistical analysis}

Data were computed by one-way ANOVA using SPSS 20 software. The statements of statistical significance were based on $p<0.05$, although $p$-values between 0.05 and 0.10 are shown and described as a trend. The variation between samples was expressed as mean with pooled SEM. Difference between means were examined using Duncan's multiple range test.

\section{RESULTS}

Feed analysis confirmed nutrient composition for amino acid content and threonine supplementation (Table 1).

\section{Growth performance and carcass charac- teristics}

The highest final body weight and carcass characteristics were observed in birds of the L-Thr supplemented group. Meanwhile, birds in the Thrdeficient group were the lowest $(p<0.05)$. There were no differences between the high $C P$ and the L-Thr supplemented group. Feed intake and FCR were not significantly affected by dietary treatments (Table 2).

The relative weight of wing and heart muscles to carcass weight were the highest in L-Thr supplemented group. Meanwhile, the Thr-deficient group was the lowest. There were no differences between the high crude protein and the L-Thr supplemented group. All other carcass characteristics were not affected by the dietary treatments (Table 3). 
Table 1 - Composition of starter ( 3 to $14 \mathrm{~d}$ ) and finisher (15 to $28 \mathrm{~d}$ ) diets.

\begin{tabular}{|c|c|c|c|c|c|c|}
\hline \multirow{2}{*}{ Ingredients, \% } & \multicolumn{3}{|c|}{ Starter } & \multicolumn{3}{|c|}{ Finisher } \\
\hline & Thr-deficient & Thr adequate-High CP & Thr adequate-L-Thr & Thr-deficient & Thr adequate-High CP & Thr adequate-L-Thr \\
\hline Treatments & G1 & $\mathrm{G} 2$ & G3 & $\mathrm{G} 1$ & $\mathrm{G} 2$ & G3 \\
\hline Corn & 53.78 & 47.72 & 53.88 & 60.49 & 56.95 & 60.54 \\
\hline Soybean meal, (CP 48\%) & 39.11 & 44.57 & 38.96 & 32.37 & 35.56 & 32.28 \\
\hline Sunflower oil & 2.73 & 3.65 & 2.7 & 3.21 & 3.74 & 3.19 \\
\hline Di Calcium Phosphate & 1.71 & 1.70 & 1.71 & 1.53 & 1.52 & 1.53 \\
\hline Limestone & 1.33 & 1.29 & 1.33 & 1.23 & 1.21 & 1.23 \\
\hline MetAMINO ${ }^{\circledR}$ & 0.33 & 0.29 & 0.33 & 0.24 & 0.22 & 0.24 \\
\hline Sodium bicarbonate & 0.32 & 0.24 & 0.32 & 0.29 & 0.24 & 0.29 \\
\hline Lysine- $\mathrm{HCl}$ & 0.2 & 0.04 & 0.21 & 0.13 & 0.03 & 0.13 \\
\hline Premix ${ }^{1}$ & 0.20 & 0.20 & 0.20 & 0.20 & 0.20 & 0.20 \\
\hline Salt & 0.2 & 0.25 & 0.19 & 0.22 & 0.25 & 0.22 \\
\hline Choline chloride $60 \%$ & 0.09 & 0.07 & 0.09 & 0.1 & 0.08 & 0.1 \\
\hline L Threonine & 0 & 0 & 0.07 & 0 & 0 & 0.04 \\
\hline Total & 100 & 100 & 100 & 100 & 100 & 100 \\
\hline Analysed supp. L-Thr & $<0.010$ & $<0.010$ & 0.08 & $<0.010$ & $<0.01$ & 0.046 \\
\hline \multicolumn{7}{|c|}{ Calculated nutritional content } \\
\hline $\mathrm{ME}, \mathrm{kcal} / \mathrm{kg}$ & 3000 & 3000 & 3000 & 3100 & 3100 & 3100 \\
\hline Crude protein & 23.33 & 25.23 & 23.33 & 20.57 & 21.68 & 20.57 \\
\hline Total methionine, (SID*) & $0.67(0.65)$ & $0.66(0.63)$ & $0.67(0.65)$ & $0.65(0.53)$ & $0.55(0.52)$ & $0.56(0.53)$ \\
\hline Total lysine, (SID) & $1.43(1.31)$ & $1.45(1.31)$ & $1.43(1.31)$ & $1.20(1.09)$ & $1.21(1.09)$ & $1.20(1.09)$ \\
\hline Total M+C, (SID) & $1.04(0.95)$ & $1.05(0.95)$ & $1.04(0.95)$ & $0.89(0.81)$ & $0.90(0.81)$ & $0.89(0.81)$ \\
\hline Total threonine (SID) & $0.89(0.76)$ & $0.98(0.83)$ & $0.96(0.83)$ & $0.79(0.67)$ & $0.84(0.71)$ & $0.83(0.71)$ \\
\hline Calcium & 0.96 & 0.96 & 0.96 & 0.87 & 0.87 & 0.87 \\
\hline Available phosphorus & 0.48 & 0.48 & 0.48 & 0.44 & 0.44 & 0.44 \\
\hline Choline, mg/kg & 1700 & 1700 & 1700 & 1600 & 1600 & 1600 \\
\hline
\end{tabular}

*SID $=$ Standardized ileal digestibility.

' Each kilogram of vitamin-mineral premix contains vitamin. $24000000 \mathrm{IU}$ of vitamin $\mathrm{A}_{1} 1000000 \mathrm{IU}$ of vitamin $\mathrm{D}_{3}, 16000 \mathrm{IU}$ of vitamin $\mathrm{E}_{,} 800 \mathrm{mg}$ of vitamin $\mathrm{K}_{3^{\prime}}, 600 \mathrm{mg}$ of vitamin $\mathrm{B}_{1}$, $1600 \mathrm{mg}$ of vitamin $B_{2^{\prime}}, 000 \mathrm{mg}$ of vitamin $B_{6^{\prime}} 6 \mathrm{mg}$ of vitamin $B_{12^{\prime}}, 40 \mathrm{mg}$ of biotin, $400 \mathrm{mg}$ of folic acid, $8000 \mathrm{mg}$ of niacin, $3000 \mathrm{mg}$ of pantothenic acid, $3000 \mathrm{mg}$ antioxidant, 80 $\mathrm{mg}$ of cobalt, $2000 \mathrm{mg}$ of copper, $400 \mathrm{mg}$ of iodine, $1200 \mathrm{mg}$ of iron, $18000 \mathrm{mg}$ of manganese, $60 \mathrm{mg}$ of selenium, $60 \mathrm{mg}$ of Zinc.

Table 2 - Growth performance and carcass parameters of broilers fed the experimental diets from d 3 to 28.

\begin{tabular}{|c|c|c|c|c|c|c|c|c|c|}
\hline \multirow[b]{2}{*}{ Treatments } & \multirow[b]{2}{*}{ BW, g } & \multicolumn{4}{|c|}{$\begin{array}{l}\text { Growth performance } \\
\qquad 1 n=8\end{array}$} & \multicolumn{4}{|c|}{$\begin{array}{l}\text { Carcass parameters } \\
\qquad{ }^{2} n=10\end{array}$} \\
\hline & & $W G, g$ & $\mathrm{Fl}, \mathrm{g}$ & FCR & EEF* & $\mathrm{LW}, \mathrm{g}$ & $C W, g$ & DY, \% & $\mathrm{BrW}, \mathrm{g}$ \\
\hline Thr-deficient & $1511.60^{b}$ & $1454.10^{b}$ & 2270.4 & 1.569 & 344.90 & $1461^{b}$ & $1034.1^{\mathrm{b}}$ & $70.8^{b}$ & 364.4 \\
\hline Thr-adequate High CP & $1542.20^{\mathrm{ab}}$ & $1484.73^{\mathrm{ab}}$ & 2288.5 & 1.561 & 353.64 & $1523.8^{\mathrm{ab}}$ & $1090.8^{\mathrm{ab}}$ & $71.6^{\mathrm{ab}}$ & 377.5 \\
\hline Thr-adequate L-Thr & $1575.80^{a}$ & $1518.33^{a}$ & 2294.2 & 1.543 & 365.94 & $1577.2^{\mathrm{a}}$ & $1143.3^{a}$ & $72.5^{a}$ & 395.4 \\
\hline SEM & 14.70 & 14.70 & 20.8 & 0.017 & 5.99 & 15.75 & 12.67 & 0.27 & 5.4 \\
\hline$p$-value & $<0.05$ & $<0.05$ & NS & NS & NS & $<0.01$ & $<0.01$ & $<0.05$ & $<0.1$ \\
\hline
\end{tabular}

a,bMeans in the same column with different superscripts differ significantly. NS: not significant. SEM: Standard error of the mean.

Sample size $={ }^{1} n=8$ birds $/$ replicate/ treatment.

Sample size $={ }^{2} n=10$ birds

$\mathrm{BW}=$ Body weight. $\mathrm{WG}=$ Weight gain. $\mathrm{Fl}=$ Feed intake. $\mathrm{FCR}=$ Feed conversion ratio (gain:feed). $\mathrm{LW}=$ Live body weight, $\mathrm{CW}=$ Carcass weight, DY= Dressing yield (CW as a percentage of $(W), B r W=$ Breast weight.

*European Efficiency Factor (EEF)= [Viability (\%) x Body weight (g)] x 100/ [age of capitalization (days) x FCR]

Table 3 - Carcass composition relative to carcass weight (as \%) of broilers fed the experimental diets at d 28.

\begin{tabular}{lcccccccc}
\hline Treatments & Wing & Heart & Thigh & Drumstick & Breast & Abdominal fat & Liver & Gizzard \\
\hline Thr-deficient & $10.01^{\mathrm{b}}$ & $0.73^{\mathrm{b}}$ & 13.85 & 12.70 & 35.24 & 1.14 & 3.25 & 4.06 \\
Thr-adequate High CP & $10.70^{\mathrm{a}}$ & $0.81^{\mathrm{ab}}$ & 14.17 & 13.05 & 34.62 & 1.08 & 3.30 & 4.16 \\
Thr-adequate L-Thr & $10.72^{\mathrm{a}}$ & $0.89^{\mathrm{a}}$ & 14.53 & 12.57 & 34.58 & 0.92 & 3.14 & 3.92 \\
SEM & 0.10 & 0.03 & 0.12 & 0.13 & 0.31 & 0.06 & 0.05 & 0.12 \\
$p$-value & $<0.01$ & $<0.05$ & NS & NS & NS & NS & NS & NS \\
\hline
\end{tabular}

a,bMeans in the same column with different superscripts differ significantly. NS: not significant Standard error of the mean. 


\section{Litter quality}

Broiler fed with the Thr-deficient diet had increased moisture content in the litter compared to broilers fed with the Thr-adequate diets $(p<0.05)$. Although moisture content was not significantly affected by dietary $C P$ level, broilers fed the high CP had greater nitrogen excretion than broilers fed the L-Thr supplemented diet. Nitrogen content of the litter was +10.3 and $+13.3 \%$ greater in the Thr-deficient and high crude protein group, respectively compared to the L-Thr Supplemented group (Table 4).

Table 4 - Effect of dietary treatments on litter moisture and nitrogen content (\%).

\begin{tabular}{lcc}
\hline Treatments & Moisture, \% & Nitrogen, \% \\
\hline Thr-deficient & $55.33^{\mathrm{a}}$ & $3.97^{\mathrm{ab}}$ \\
\hline Thr-adequate High CP & $45.33^{\mathrm{b}}$ & $4.08^{\mathrm{a}}$ \\
\hline Thr-adequate L-Thr & $43.67^{\mathrm{b}}$ & $3.60^{\mathrm{b}}$ \\
SEM & 2.10 & 0.08 \\
$p$-value & $<0.05$ & $<0.05$ \\
\hline
\end{tabular}

$a, b$ Means in the same column with different superscripts differ significantly. NS: not significant. Standard error of the mean.

\section{Histological parameters}

The highest duodenum villus length and villus to crypt ratios were observed in the Thr-adequate groups, while the lowest values were seen in the Thr-deficient group $(p<0.05)$. Crypt depth was not affected by dietary treatments. Histological parameters were similar in the adequate-Thr groups (Table 5).

\section{DISCUSSION}

Diets for the Thr-deficient group (G1) and Thradequate L-Thr group (G3) were formulated to be iso-energetic and iso-proteinaceous but the limitation in dietary Thr in diet $\mathrm{G} 1$ resulted in a poor performance and carcass characteristics. Meanwhile, dietary fortification of Thr from raw materials (G2) resulted in an increase in $\mathrm{CP} \%$ level. This fortification however, improved the broiler performance and carcass characteristics numerically when compared to
Thr-deficient group (G1). Birds responded better with L-Thr supplementation (G3) than Thr adequate high CP (G2). FCR improved numerically with L-Thr group (G3). This can be explained on the basis that CP needs to be broken down into amino acids and the excess nitrogen will be converted into uric acid, which is expensive in terms of energy consumption (Alleman \& Leclerq 1997). Our results are more or less in line with Khan et al. (2008) who revealed that a marginal dietary deficiency of digestible Thr can result in economic losses due to increased FCR and reduced breast meat yield. However, under our experimental condition, FCR and breast meat weight showed a numerical improvement on dietary Thr fortification. Meanwhile, relative breast yield was not affected by such dietary Thr fortification. Rezaeipour et al. (2012) observed an improvement in the growth performance of broiler as a result of the effect of different inclusion rate of dietary L-Thr meanwhile, such fortification did not improve carcass characteristics in a significant manner. Moreover, AlHayani (2017) concluded that fortification of the diet with $900 \mathrm{mg} / \mathrm{kg} \mathrm{L}$-Thr resulted in an improvement in overall physiological and productivity traits. Our results concerning histological parameters showed the dietary limitation of Thr had a pronounced negative impact in both duodenum villi length and villus: crypt ratio. The dietary fortification of Thr either from raw material or from L-Thr supplementation had a pronounced positive impact on aforementioned parameters. This can be explained on the basis that a large portion of dietary Thr is used for the synthesis of intestinal mucosal proteins, such as mucin (Corzo et al. 2007). Mucin amount is crucial especially with higher levels and varied composition of dietary fibre as it can alter the amount and type of mucin produced within the gut (Wils-Plotz \& Dilger 2013). Additionally, Mucins act as a physical barrier against foreign pathogens and protect the intestinal cells from digestive enzymes and acids (Kim \& Ho 2010). Our data is in agreement with Zaghari et al. (2011) who concluded that gut functionality seemed to be improved with increasing dietary digestible Thr levels. Moreover, Rezaeipour et al. (2012) observed that the villi length and crypt

Table 5 - Effect of dietary treatments on villus height and crypt depths at duodenum of broilers at $28 \mathrm{~d}$.

\begin{tabular}{|c|c|c|c|}
\hline Treatments & Villus length $\mu \mathrm{m}$ & Crypt depths $\mu \mathrm{m}$ & Villus: Crypt \\
\hline Thr-deficient & $830.90^{\mathrm{b}}$ & 147.1 & $5.65^{b}$ \\
\hline Thr-adequate High CP & $1137.4^{\mathrm{a}}$ & 156.6 & $7.26^{\mathrm{ab}}$ \\
\hline Thr-adequate L-Thr & $1202.4^{\mathrm{a}}$ & 143.6 & $8.37^{a}$ \\
\hline SEM & 28.47 & 9.38 & 0.44 \\
\hline$p$-value & $<0.001$ & NS & $<0.05$ \\
\hline
\end{tabular}

a,bMeans in the same column with different superscripts differ significantly. NS: not significant. Standard error of the mean. 
depth were increased in both jejunum and ileum segments as a result of the dietary L-Thr fortification. Our data concerning litter moisture and nitrogen content showed dietary Thr fortification either from high crude protein or L-Thr resulted in a significant reduction in the litter moisture compared with $\mathrm{Thr}$ limited group. Interestingly, it was expected that high crude protein would have the greatest impact on litter moisture content. This can be explained on the basis that Thr fortification maintained the gut integrity and immunity (Chen et al. 2017). Dietary limitation of Thr may cause varying degree of intestinal damage due to limited mucin production that may increase the probability of bacterial invasion that may increase the intestinal movement and therefore water loss (Koutsos \& Arias 2006). Dietary fortification of Thr from high crude protein resulted in an expected increase in litter nitrogen content in a significant manner compared with L-Thr adequate group. However, it was not significantly different to the Thr-deficient group. That can be explained according to ideal protein concept; ideal amino acids ratio will maximize the nitrogen utilization (Emmert \& Baker 1997). Additionally, 1\% decrease in dietary crude protein are associated with a $7 \%$ decrease (Faria Filho et al. 2005) or 10\% decrease in nitrogen excretion (Cauwenberghe \& Burnham 2001; Si et al. 2004).

\section{CONCLUSIONS}

It could be concluded that, the broiler chickens responded positively to dietary fortification of L-Thr as it had the potential to improve growth performance and carcass characteristics as indicated by its effect on final body weights, dressing yields, carcass weights, relative wings, and heart weights. Balancing amino acids with supplemented L-Thr had the potential to improve, water and nitrogen utilization, to improve duodenal villi length and villi: crypt ratio. Overall, the results of this experiment showed that correcting an inadequate provision of dietary Thr with L-Thr supplementation allows poultry nutritionists to reduce dietary CP levels while improving final BW, carcass traits, intestinal integrity, and litter quality.

\section{ACKNOWLEDGEMENT}

The authors express their sincere gratitude and appreciation to King Abdulaziz City for Science and Technology (KACST) for rendering its facilities for conducting this study. They would also like to extent their thanks to Evonik Degussa GmbH as the current project was funded by this organization.

\section{REFERENCES}

Aletor VA, Hamid II, Nieb E, Pfeffer E. Low-protein amino acid-supplemented diets in broiler chickens: effects on performance, carcass characteristics, whole-body composition and efficiencies of nutrient utilization. Journal of Science Food Agriculture 2000;80:547-554.

Al-Hayani WK. Effect of threonine supplementation on broiler chicken productivity traits. International Journal of Poultry Science 2017;16(4):160-168.

Alleman F, leclercq B. Effects of dietary protein and environmental temperature on growth performance and water consumption of male broiler chickens. British Poultry Science 1997;38:607-610.

Caruso M, Demonte A, Neves VA. Histomorphometric study of role of lactoferrin in atrophy of the intestinal mucosa of rats. Health 2012;4(12):1362-1370.

Cauwenberghe S, Burnham D. New developments in amino acid protein nutrition of poultry, as related to optimal performance and reduced nitrogen excretion. Proceedings of 13th European Symposium on Poultry Nutrition, 2011 Sept 30- 4 Oct; Blankenberge, Belgium; 2011. p.141-149.

Chen YP, Cheng YF, Li XH, Wen C, Zhou YM. Effects of threonine supplementation on the growth performance, immunity, oxidative status, intestinal integrity, and barrier function of broilers at the early age. Poultry Science 2017;96(2):405-413

Corzo A, Kidd MT, Dozier WA, Pharr GT. Dietary threonine needs for growth and immunity of broilers raised under different litter conditions. The Journal of Applied Poultry Research 2007;16(4):574-582.

Emmert J, Baker, D. Use of the ideal protein concept for precision formulation of amino acid levels in broiler diets. The Journal of Applied Poultry Research 1997;6(4):462-470.

Everett DL, Corzo A, Dozier WA, Tillman PB, Kidd MT. Lysine and threonine responses in Ross TP16 male broilers. Journal of Applied Poultry Research 2010;19(4):321-326.

Faria Filho DE, Rosa OS, Vieira BS, Macari M, Furlan RL. Protein levels and environmental temperature effects on carcass characteristics, performance, and nitrogen excretion of broiler chickens from 7 to 21 days of age. Brazilian Journal of Poultry Science 2005;7:247-253.

Khan AR, Nawaz H, Zahoor I. Effect of different levels of digestible threonine on growth performance of broiler chicks. Journal of Animal Poultry Science 2008;16(12):1-4.

Kidd MT, Tillman PB. Key principles concerning dietary amino acid responses in broilers. Animal Feed Science and Technology 2016;221:314-322.

Kim YS, Ho SB. Intestinal goblet cells and mucins in health and disease: Recent insights and progress. Current Gastroenterology Reports 2010;12:319-330.

Koutsos E, Arias V. Intestinal Ecology: interactions among the gastrointestinal tract, nutrition, and the microflora. The Journal of Applied Poultry Research 2006;15(1):161-173.

Mehri M, Davarpanah AA, Mirzaei HR. Estimation of ideal ratios of methionine and threonine to lysine in starting broiler chicks using response surface methodology. Poultry Science 2012;91:771-777.

Rezaeipour V, Fononi $\mathrm{H}$, Irani M. Effects of dietary L-threonine and Saccharomyces cerevisiae on performance, intestinal morphology and immune response of broiler chickens. South African Journal Animal Science 2012;42:266-273. 
Ruth MR, Field CJ. The immune modifying effects of amino acids on gut associated lymphoid tissue. Journal of Animal Science Biotechnology 2013;4:27.

Si J, Fritts CA, Waldroup PW, Burnham DJ. Effects of excess methionine from meeting needs for total sulfur amino acids on utilisation of diets low in crude protein by broiler chicks. Journal of Applied Poultry Research 2004;13:579-587.
Wils-Plotz E, Dilger R. Combined dietary effects of supplemental threonine and purified fiber on growth performance and intestinal health of young chicks. Poultry Science 2013;92(3):726-734.

Zaghari M, Zaefarian F, Shivazad M. Standardized lleal digestible threonine requirements and its effects on performance and gut morphology of broiler chicks fed two levels of protein. Journal of Agricultural Science and Technology 2011;13(4):541-552. 